\title{
An Investigation of the Recovery of Silicon Photovoltaic Cells by Application of an Organic Solvent Method
}

\author{
P. M. Tembo ${ }^{\mathrm{a}}$, M. Heninger ${ }^{\mathrm{b}}$, V. Subramanian ${ }^{\mathrm{a}}$ \\ a Department of Chemical and Materials Engineering, University of Nevada-Reno, Reno, \\ Nevada 89557, USA \\ ${ }^{\mathrm{b}}$ Enel Green Power North America, Inc., Reno, Nevada 89502, USA
}

\begin{abstract}
The treatment of photovoltaic (PV) waste is gaining traction the world over, with the recovery of valuable materials from end-of-life, or damaged and out-of-spec polycrystalline silicon PV modules. These materials are a focus of recycling. However, the current recycling practices usually involve excessive damage to PV cells that could otherwise be reused if extracted undamaged. The ability to extract undamaged PV cells, capable of reuse, would serve to further reduce the carbon footprint and cost associated with PV module manufacturing. This study focuses on the recovery of silicon PV cells from end-of-life PV modules by application of an organic solvent method. Herein, recovery tests were carried out in which silicon PV cells were recovered relatively undamaged with the application of hexane as solvent. XRD measurements showed that the recovered PV cells could be used in the fabrication of new PV modules.
\end{abstract}

\section{Introduction}

The $21^{\text {st }}$ century has seen a growing call to address the issue of shifting from conventional to more sustainable energy sources. The result of which has been a growing interest in renewable energy. Chief among these are photovoltaic (PV) energy systems which have been bolstered by favorable government policies, improved efficiencies and reduction in production cost (1). As such, the dependence on PVs for both commercial and domestic purposes has constantly increased over the past 30 years (2). Studies have shown that the lifetime of silicon-based commercial PV modules is between 20-30 years, after which, their performance is greatly deteriorated (3) (4) (5). The lifetime of PV modules is affected by factors such as thermal stress induced breakage of interconnecting wires and encapsulant deterioration (5) (6). As the utilization of PV systems continues to grow, an exponential increase in the number of end-of-life PV modules is predicted (7). Consequently, this has brought about the notion of exploring recycling processes for end-of-life PV modules. The idea is to provide much needed material for the manufacture of new PV modules while addressing the matter of waste management and minimization. Recycling of end-of-life modules could also alleviate the energy burden associated with the fabrication of crystalline-silicon solar cells via the Siemens process (1) (8). The process is reported to be one of the most energy intensive stages in the production of silicon PV modules (9). Silicon wafer production is also reported to account for $50 \%$ or more of the environmental footprint of a crystalline-silicon PV module (10). Previous experimental work has shown that glass, aluminum, silicon, copper and silver can be recovered from the recycling of end-of-life PV 
modules (11) (12). Several processes have been suggested in which the initial step is the mechanical removal of the aluminum frame, junction box and wiring (7) (13) (14). This is followed by the delamination of the PV module. Tempered glass, ethylene vinyl acetate (EVA) encapsulant, encapsulated PV cells and back-sheet material (typically Tedlar ${ }^{\circledR}$ ) make up the PV sheet as shown in Figure 1, which is typically crushed and treated to recover the various constituents (4) (7) (14) (15) (16).

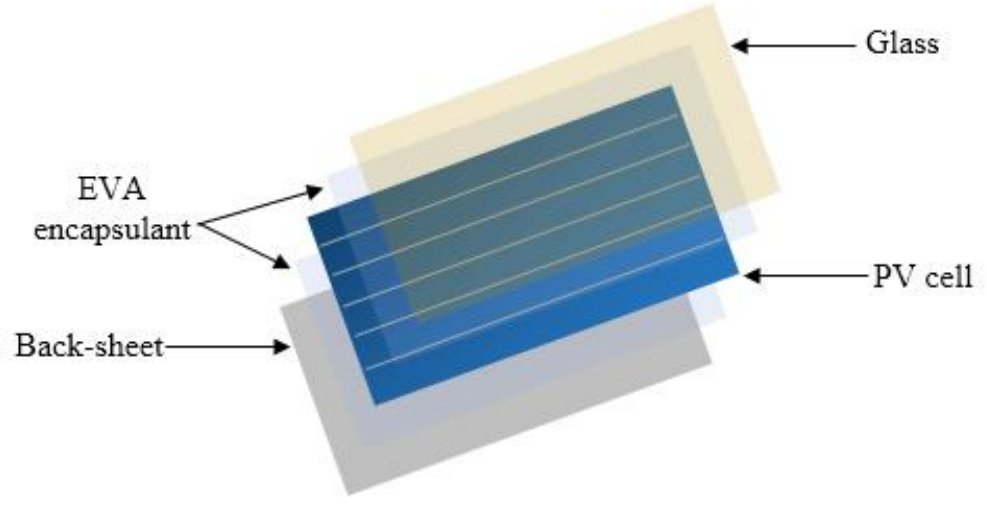

Figure 1. Exploded view of the PV sheet layers.

The EVA encapsulant acts as an adhesive to hold the PV sheet together as well as protecting the PV cells from exposure to air and moisture (11). Different methods, summarized in Table I, are applied to the resultant crushed particles (17) in a bid to separate the various materials making up the particles.

TABLE I. Methods Applied to Separate the Various Constituents of end-of-life PV Module.

\begin{tabular}{|c|c|c|}
\hline Process & Advantages & Disadvantages \\
\hline Pyrolysis (18) (19) & $\begin{array}{c}\text { Complete removal of EVA } \\
\text { Cells can be recovered } \\
\text { undamaged } \\
\text { Economically feasible }\end{array}$ & $\begin{array}{c}\text { High energy demand } \\
\text { Emission generation } \\
\text { Defects and degradation of cells }\end{array}$ \\
\hline Mechanical processing (14) (20) & $\begin{array}{l}\text { High volume treatment } \\
\text { Economically viable }\end{array}$ & $\begin{array}{c}\text { Incomplete separation } \\
\text { Heavy metal dispersal into the } \\
\text { atmosphere } \\
\text { Damage to solar cells }\end{array}$ \\
\hline $\begin{array}{l}\text { Organic solvent dissolution (5) } \\
\qquad(21)\end{array}$ & $\begin{array}{l}\text { Low cell damage } \\
\text { Recovery of glass }\end{array}$ & $\begin{array}{c}\text { Can take long periods of time } \\
\text { Possibly harmful waste and } \\
\text { emissions }\end{array}$ \\
\hline $\begin{array}{l}\text { Inorganic solvent dissolution } \\
\qquad(22)\end{array}$ & $\begin{array}{l}\text { Cells can be recovered } \\
\text { undamaged } \\
\text { EVA and metal coatings can be } \\
\text { completely removed }\end{array}$ & $\begin{array}{c}\text { Can result in cell defects } \\
\text { Harmful waste and emissions }\end{array}$ \\
\hline Chemical etching (23) & $\begin{array}{l}\text { High purity metals can be } \\
\text { recovered }\end{array}$ & $\begin{array}{c}\text { Harmful waste and emissions } \\
\text { Damage to solar cells }\end{array}$ \\
\hline
\end{tabular}

Experiments have also been carried out to try and obtain the PV cells intact, without having to crush the modules (5) (24). A challenge commonly faced during this process is the swelling of the EVA layers which results in the cracking of the PV cells. A process incorporated by Doi and colleagues involved a method involving the application of a counter pressure to offset the pressure induced by EVA swelling (5). It is reported that the use of trichloroethylene as the solvent resulted in the recovery of undamaged PV cells. The ability to obtain the PV cells intact would greatly help in reducing the cost of production 
of the PV modules, however reports indicate that this too has its drawbacks. Chief among these drawbacks is the concern about the quality of recovered silicon. Silicon quality is generally divided into three grades: metallurgical, solar, and semiconductor-grade silicon. Owing to contamination during the recovery process, the obtained silicon is assumed to be of metallurgical-grade, wherein the price differential between solar-grade and metallurgical-grade silicon is estimated at US $\$ 8 / \mathrm{kg}$ or higher (25). This essentially means that the ability to obtain higher purity silicon - capable of being assimilated into the higher cost sections of the supply chain - from the recycling process would be invaluable. The use of organic solvent for the delamination of the silicon cells is most appealing when the goal is to recover the silicon cells with minimal defects thereby improving the capability to maintain the silicon grade.

\section{$\underline{\text { EVA Polymer Dissolution }}$}

The free radical polymerization between ethylene and vinyl acetate (VA) results in the formation of EVA (26). The transport processes involved in the dissolution of polymers into a solvent are chain disentanglement and solvent diffusion, shown in Figure 2, leading to the formation of a gel layer. Diffusion of the solvent into the polymer occurs when the solvent is thermodynamically compatible with the amorphous, uncrosslinked polymer. Two forms of polymer dissolution are normal dissolution, which involves the formation of a gel layer, a phenomenon referred to as plasticization and dissolution which occurs in the absence of the gel layer (27). It has been suggested that the polymer dissolution surface layer phenomena are comprised of three regimes: 1) the concentrated regime, 2) semidilute regime, and 3) dilute regime (28). The concentrated regime is made up of the polymer glassy state while the semi-dilute regime consists of the gel-like layer and finally the dilute regime is made up of the solvent layer. According to Ueberreiter (29), the solvent initially pushes the swollen polymer into the solvent then a more dilute upper layer is transferred towards the solvent. The swollen polymer surface layer increases as the solvent penetrates further until the transport of the molecules from the surface into the solution prevents the layer from increasing any further (29). Based on the dissolution process described by Ueberreiter, the structure of the surface layers of glassy polymers can be summarized as in Figure 2.

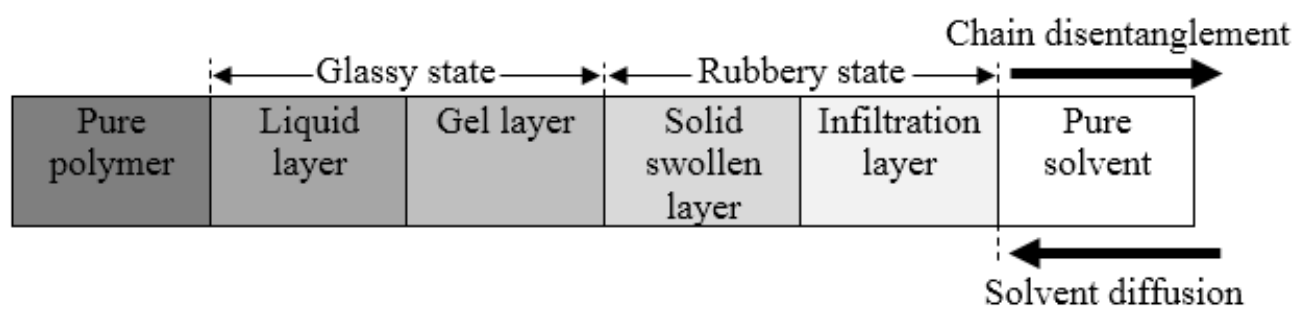

Figure 2. A one-dimensional schematic of polymer dissolution and solvent diffusion (30).

The EVA dissolution process follows the normal dissolution model, in which the solvent results in the plasticization of the polymer leading to the formation of a swollen gel-like polymer layer. It is an established fact that the type of solvent has a profound effect on polymer dissolution (27). In a study performed by Ouano and Carothers (31) on the dissolution of polymers, the conclusion made was that "if the 'internal pressure' builds up faster than the glassy matrix can relax through gradual swelling, catastrophic fracture could 
result." In carrying out the dissolution of the EVA by application of an organic solvent, it is therefore paramount to understand these key principles involved in polymer dissolution.

\section{Experimental Procedure}

The experimental procedure involved cutting PV sections from commercial end-of-life PV modules followed by the extraction of silicon PV cells, mainly by the application of an organic solvent under various conditions. The details are given below.

\section{$\underline{\text { Photovoltaic Modules }}$}

PV sheet sections were manually cut from standard $330 \mathrm{~W}$ commercial end-of-life (polycrystalline-silicon type) PV modules obtained from Enel Green Power North America, Inc.'s commercial PV facility that had been in the field for approximately 10 years. The PV modules had a fragmented glass layer consisting of $0.5-1 \mathrm{~cm}$ fragments that were still fully attached to the PV cells. Care was taken during the cutting process to obtain sections of approximately 17 x $17 \mathrm{~cm}$ whilst other sections measured 14 x $14 \mathrm{~cm}$. All sections that were cut out consisted of the typical constituents of a PV sheet: tempered glass, EVA layers, silicon PV cells and the Tedlar ${ }^{\circledR}$ back-sheet. Figure 3 shows images of a polycrystalline-PV module and the resulting PV sheet sections obtained from it that were used during the experiment.

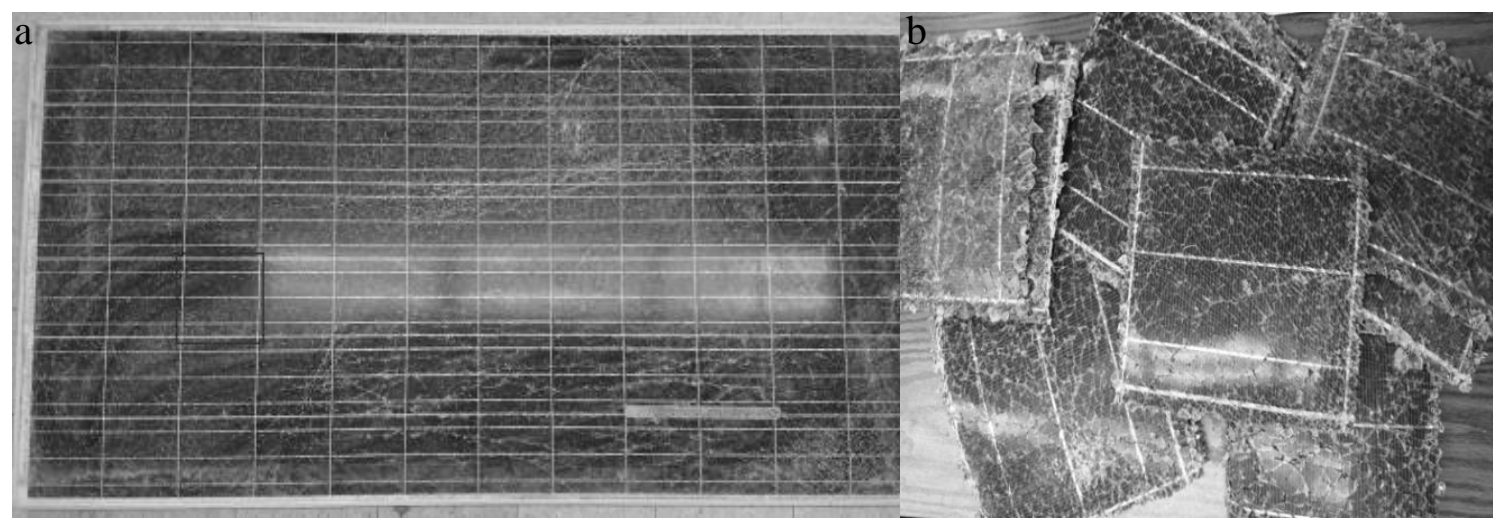

Figure 3. A photograph of a) an end-of-life polycrystalline-PV module and b) extracted PV sheet sections used during the experiments.

The extracted PV sheet sections were next subjected to solvent treatment in order to extract the PV cells. Acetone, hexane, iso-propanol, p-toluenesulfonic acid monohydrate (PTA) and toluene were initially selected for the dissolution process. Initial stages of the extraction process involved immersing 7 x $7 \mathrm{~cm}$ PV sheet sections into $300 \mathrm{ml}$ of pure solvent at room temperature for 24 hours. After this step, ultrasonication was performed for $10,15,20$, and 40 minutes. Acid treatment using hydrochloric acid was additionally performed on some of the samples.

On establishing the solvents that gave the best results, the process was repeated on PV sheet sections containing complete PV cells. Various conditions were altered in order to ascertain the dissolution behavior of the EVA. EVA dissolution may be considered to be governed by four important factors: a) the type of solvent, b) operating temperature which 
contributes towards the thermodynamics of the process, c) the surface area exposed to the solvent, and d) agitation/mixing (mass transfer parameter). In this work the conditions investigated were the effect of temperature, solvent type, concentration and penetration. The tests involved placing the cell sections in glass vessels immersed in a water bath, maintaining the solvent temperature at a predetermined value as shown in Figure 4. A condenser was attached to each vessel to recover vaporized solvent as can be seen on the actual experimental setup shown in Figure 5.

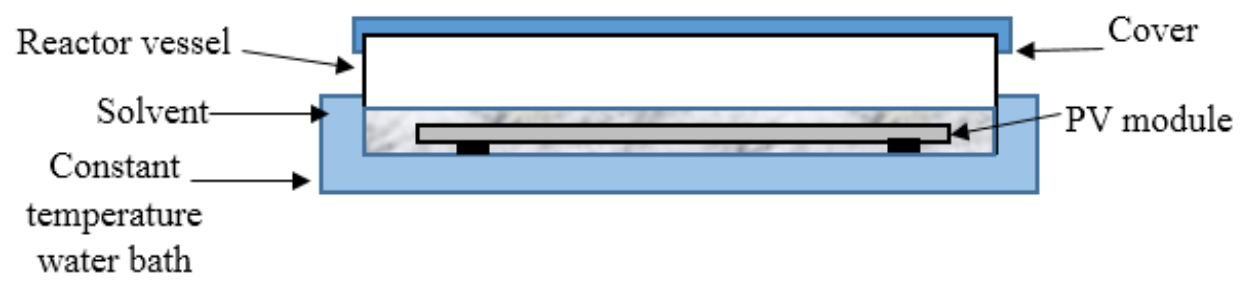

Figure 4. Schematic of the experimental setup.

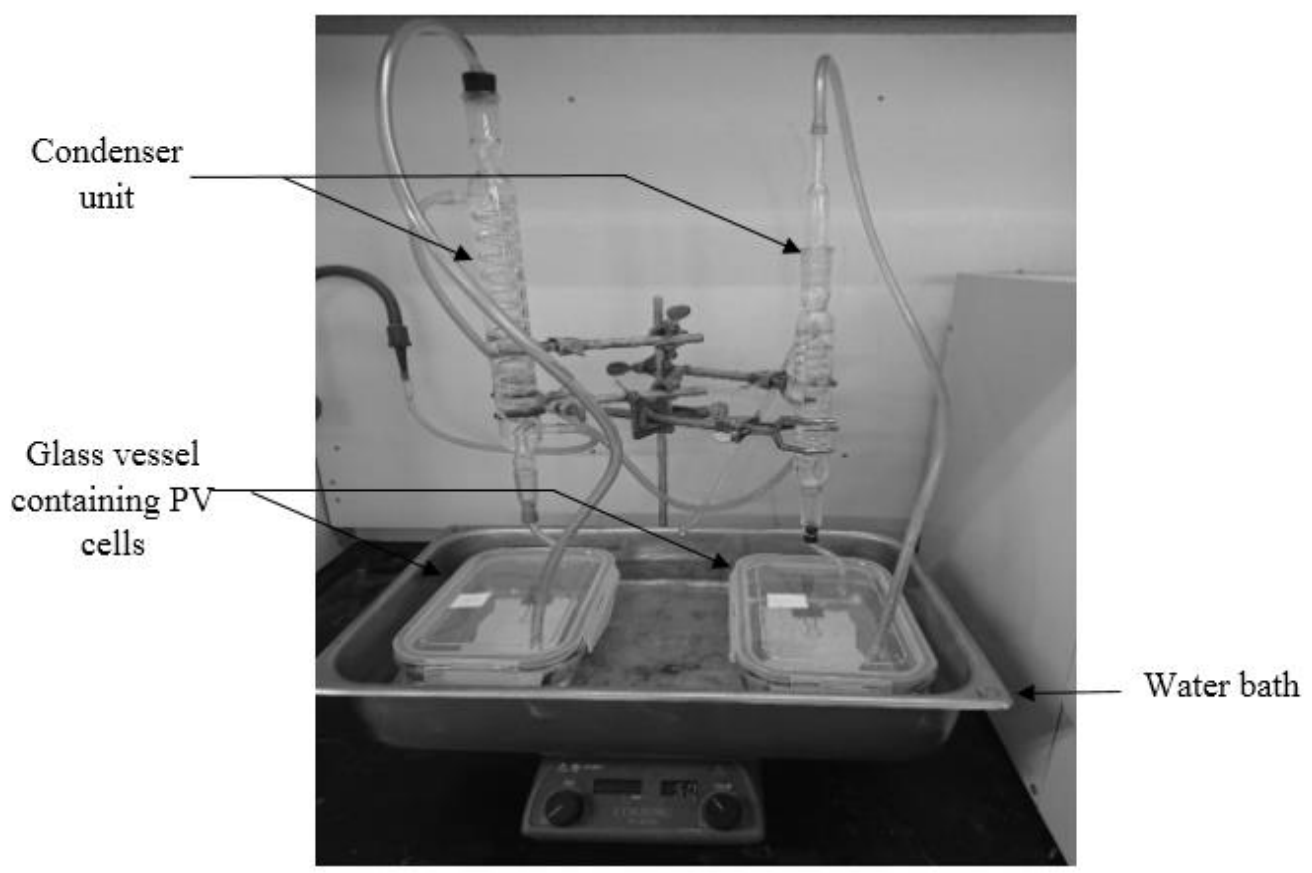

Figure 5. Silicon PV cell recovery experimental setup.

The PV sheet sections were initially immersed in solvent for a 24-hour period, at varying temperatures. The solvent temperature range used was $60-90{ }^{\circ} \mathrm{C}$ with $10{ }^{\circ} \mathrm{C}$ increments. This was then followed by repeating the same process but for varying solvent concentrations at a predetermined temperature. Finally, the effect of ultrasonication coupled with solvent concentration differences was investigated. The flow diagram shown in Figure 6 highlights the experimental procedure conducted. 


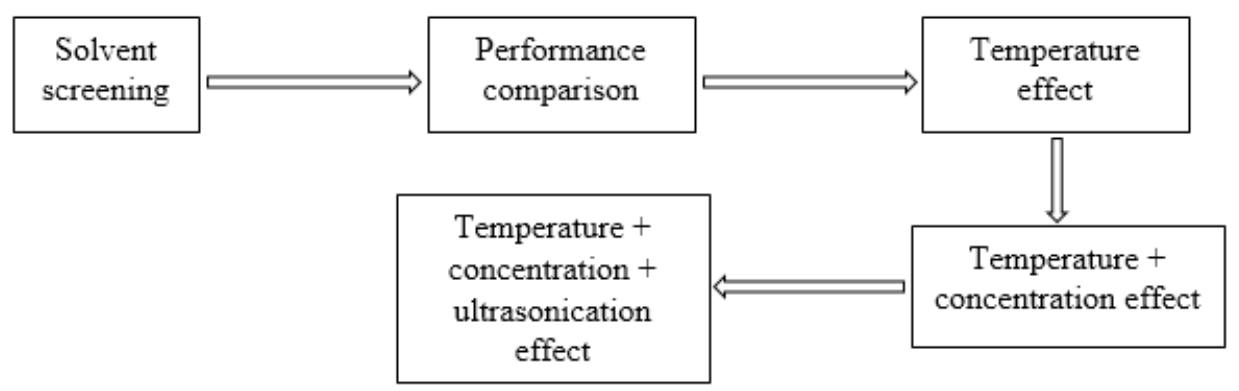

Figure 6. Experimental procedure flow diagram.

\section{Results and Discussion}

To extract the silicon PV cells from the PV sheet sections, several experiments were performed: initially using various organic solvents during the solvent screening process. The various solvents, test conditions applied, and the results obtained from each test are shown in Table II. No EVA dissolution and consequently no PV cell extraction was visually observed when non-acidified acetone, iso-propanol and PTA was used, with and without ultrasonication. Furthermore, tests involving acidified and non-acidified hexane and toluene resulted in the extraction of PV cells. Non-acidified toluene, ultrasonicated at ambient conditions as well as acidified toluene resulted in complete PV cell extraction, albeit the cells were fractured. Acidified iso-propanol also resulted in the dissolution of the EVA and the partial extraction of the PV cells but however, the solvent showed clear signs of reacting with the silicon PV cells which would result in defects within the cells.

TABLE II. Organic Solvents Used and the Varying Operating Conditions Employed.

\begin{tabular}{|c|c|c|}
\hline Solvent & Ambient Conditions & $\begin{array}{c}\text { Ambient Conditions + } \\
\text { Ultrasonication }\end{array}$ \\
\hline Acetone & $\mathrm{NE}$ & $\mathrm{NE}$ \\
\hline Hexane & PE & $\mathrm{PE}$ \\
\hline Iso-propanol & NE & NE \\
\hline Toluene & $\mathrm{PE}$ & $\mathrm{E}$ \\
\hline PTA & $\mathrm{NE}$ & $\mathrm{NE}$ \\
\hline A-Acetone & $\mathrm{NE}$ & $\mathrm{NE}$ \\
\hline A-Hexane & PE & $\mathrm{PE}$ \\
\hline A-Iso-propanol & PE & $\mathrm{PE}$ \\
\hline A-Toluene & $\mathrm{E}$ & $\mathrm{E}$ \\
\hline A-PTA & $\mathrm{NE}$ & $\mathrm{NE}$ \\
\hline
\end{tabular}

Figure 7 shows results from the initial treatment using acidified hexane. EVA dissolution occurred resulting in the separation of the cell section to give the back-sheet, metal electrodes and silicon PV cell. Some of the tempered glass remained attached to the silicon PV cell. However, visual inspection of the PV cell showed that parts of the cell had been eroded. 

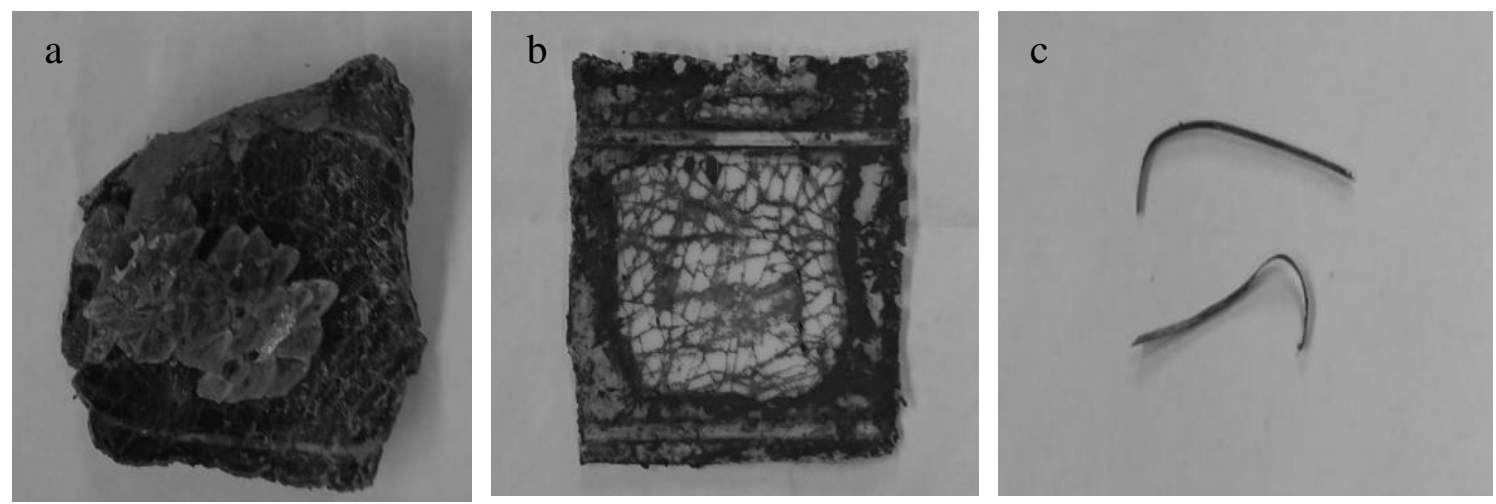

Figure 7. Components of partially extracted silicon PV cell using acidified hexane a) silicon PV cell with some tempered glass and EVA still attached, b) back-sheet, c) electrodes.

With the solvent screening stage completed, the results indicated that hexane and toluene would be suitable solvents for the PV cell extraction process. Furthermore, it was made clear that acidification of the organic solvents had a negative impact on the PV cells. To quantitatively measure the solvent performance for performance comparison, the percentage detachment was used. The percentage detachment considers the combined detachment of the glass, EVA and silicon PV cell from the back-sheet. A similar approach was utilized by Azeumo and colleagues, in which the back-sheet mass was evaluated based on the specific surface density of the back-sheet material (7). The result obtained from our tests was a back-sheet specific surface density of $0.72 \mathrm{~g} / \mathrm{cm}^{3}$.The mass of the back-sheet (assumed to remain constant throughout the EVA dissolution process) was subtracted from the mass obtained before and after the EVA dissolution to obtain the initial $\left(\mathrm{m}_{\mathrm{i}}\right)$ and final $\left(\mathrm{m}_{\mathrm{f}}\right)$ mass of the other PV sheet section constituents. The percentage detachment $(\delta)$ is given by Equation 1 as:

$$
\delta=\left(\left(m_{i}-m_{f}\right) * 100\right) / m_{i}
$$

Using the expression, percentage detachment was estimated and plotted. It can be seen from Figure 8 that toluene has a superior dissolution capability compared to hexane at ambient conditions. However, the results from the experiments showed that toluene causes the complete fracturing of the PV cells. This can be attributed to the initial interaction between toluene and the EVA layer which results in the dissolution process occurring in the absence of the gel layer. The internal pressure builds up faster than the polymer can swell resulting in the fracturing of the polymer. As a result of the polymer-PV cell contact, the stress induced by the polymer fracturing extends to the PV cells, which would explain why the PV cells fractured. This was further supported by evidence from experiments in which the internal pressure build-up was offset using binders. Even with application of the external pressure, the PV cells still fractured. The polymer eventually formed a gel layer which was seen on the solvent surface after the fracturing of the PV cells. On the other hand, hexane resulted in the recovery of relatively intact PV cells. This can be attributed to an EVA internal pressure build up that does not far exceed the swelling rate of the polymer thereby allowing for the gradual formation of the gel layer without any fracturing of the polymer. 


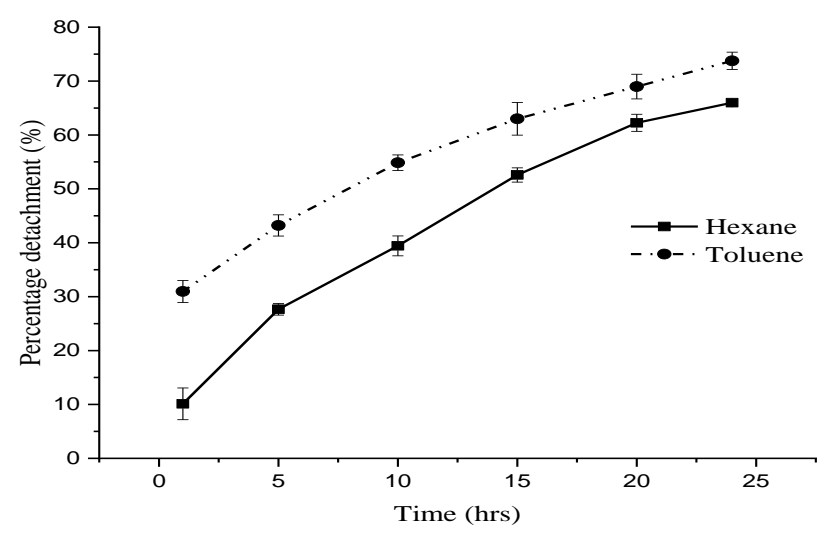

Figure 8. Percentage detachment resulting from EVA dissolution at $25^{\circ} \mathrm{C}$.

The application of toluene as a solvent for the dissolution of EVA has been investigated and reported (7) (21). The inference drawn from this experiment is that hexane can be a superior solvent for extraction of PV cells with minimal to no damage. Varying the temperature at which the PV cell recovery process was carried out for hexane yielded the results shown in Figure 9. An increase in the operating temperature improved the PV cell recovery process. A temperature of $70{ }^{\circ} \mathrm{C}$ was found to be an optimum operating temperature for the hexane-assisted EVA dissolution process. This is slightly above the boiling point of hexane which is $66{ }^{\circ} \mathrm{C}(32)$. By using boiling hexane, the dissolution process is greatly improved. This can be seen by the marked increase in the percentage detachment between $60{ }^{\circ} \mathrm{C}$ and $70{ }^{\circ} \mathrm{C}$. After 15 hours, the dissolution performance was found to be comparable to that of the higher temperatures.

However, even at these higher temperatures the back-sheet remained attached to the PV cells. This may be attributed to the contact between the solvent and the EVA layer on the back surface. Owing to the cracked glass on the front surface of the PV sheet, the contact between the solvent and the front EVA layer was enhanced. Since the back-sheet was fully intact, such contacting was not possible. An attempt at effecting complete detachment of the PV cells from the polymer back-sheet involved increasing the operating temperature. The temperature was increased up to $120{ }^{\circ} \mathrm{C}$ which resulted in complete separation of the silicon PV cells from the back-sheet but however the cells were completely fractured. The results indicate that $70{ }^{\circ} \mathrm{C}$ is the optimal temperature for extraction using hexane. Raising the temperature any further has minimal impact when the aim is to obtain undamaged PV cells. 


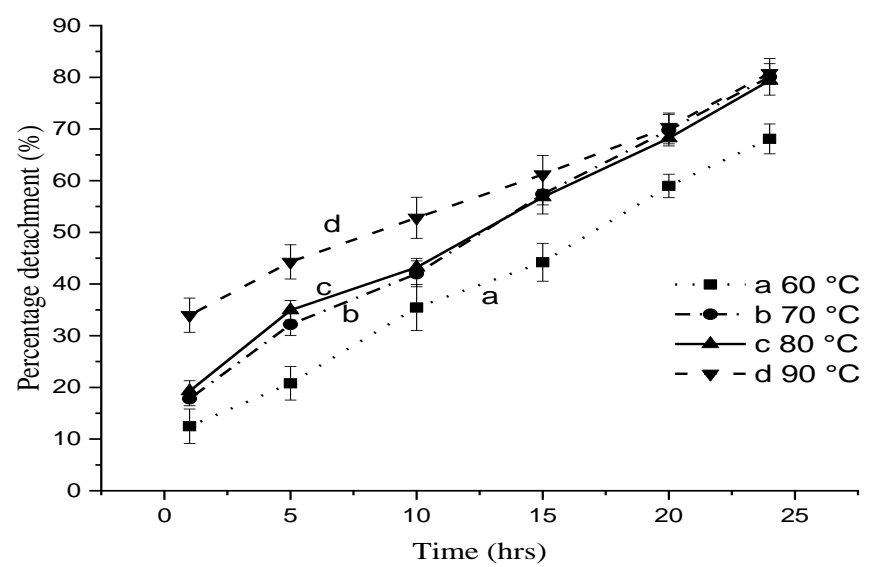

Figure 9. Percentage detachment when hexane is used at different temperatures.

The effect of hexane solvent concentration on the EVA dissolution was investigated next. Various hexane concentrations were selected, and the dissolution experiments were repeated at $70{ }^{\circ} \mathrm{C}$. The different concentrations were prepared by diluting known volumes of hexane with calculated amounts of deionized water. The hexane concentrations that were investigated were: $1 \mathrm{M}, 2 \mathrm{M}, 5 \mathrm{M}$ and pure hexane. Figure 10 shows that the solvent concentration does not have a significant initial impact on the EVA dissolution with the highest percentage detachment obtained with the use of pure hexane. The lower hexane concentrations have different initial EVA dissolution rates shown by the differences in the percentage detachments. However, this difference greatly diminishes after 10 hours of contacting the PV sheet section with the hexane solvent. The performances of the different concentrations become somewhat similar without much distinction.

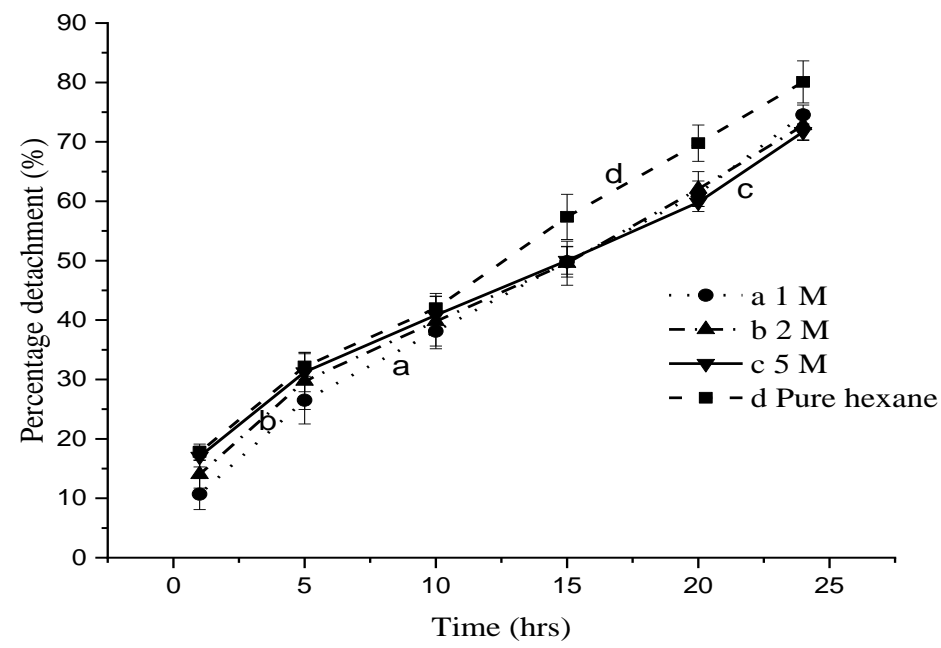

Figure 10. Percentage detachment when different hexane concentrations are used at 70 ${ }^{\circ} \mathrm{C}$.

The effect of ultrasonication was also investigated on the various hexane concentrations at $70{ }^{\circ} \mathrm{C}$. Ultrasonication for 15 minutes was used as a pretreatment method, after which the samples were subjected to the dissolution process at $70{ }^{\circ} \mathrm{C}$. The results from the tests show 
that ultrasonication improves the overall EVA dissolution process for the different hexane concentrations as indicated in Figure 11. The greatest EVA dissolution was obtained when pure hexane was used. The apparent dissolution rate decreases across all the concentrations after 15 hours of contacting.

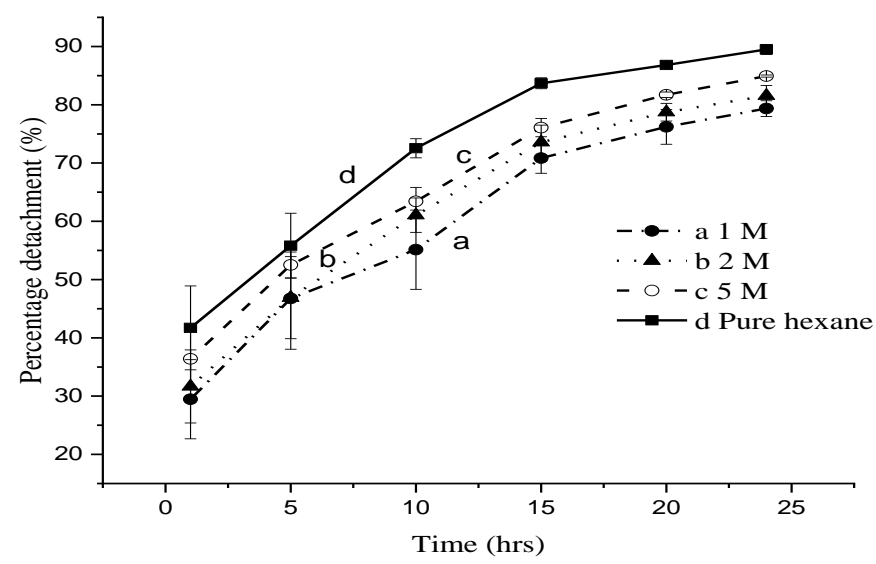

Figure 11. Percentage detachment achieved using ultrasonication and different hexane concentrations are at $70{ }^{\circ} \mathrm{C}$.

\section{$\underline{\text { XRD Characterization }}$}

The recovered silicon PV cells were characterized using XRD. Due to the attached back-sheet material, the XRD spectra of the silicon cell front was obtained. The spectra were obtained from two different points on the PV cell to test for surface structure homogeneity. From Figure 12, the XRD peaks characteristic of the front surface of the PV cell were detected. These peaks correspond to silver (Ag) since silver paste is typical of the cell front surface. Therefore, it can be surmised that the silicon PV cell front surface is relatively intact, and that the hexane did not have adverse effects on the PV cell front surface constituents, mainly the silver.

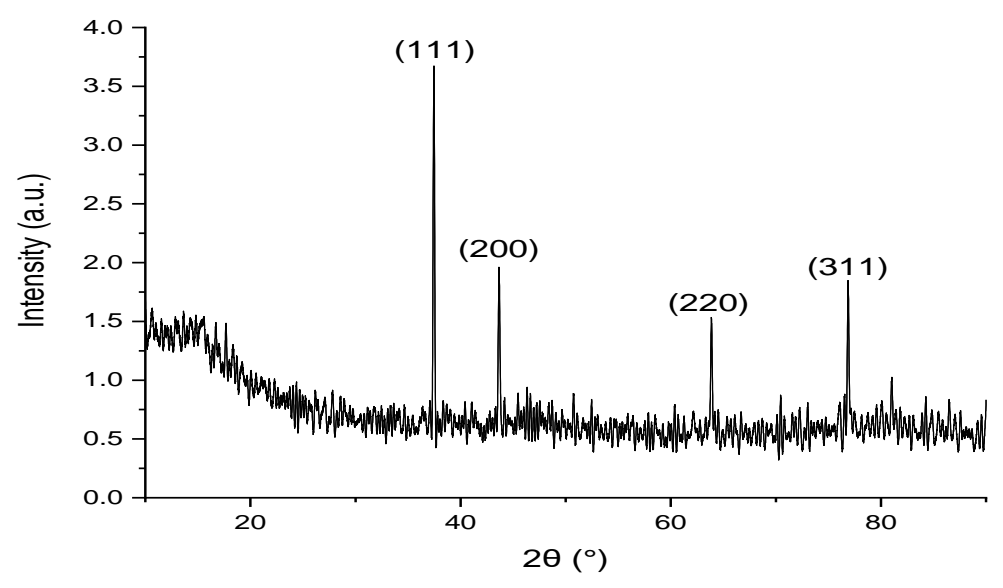

Figure 12. XRD pattern of the front surface of the silicon PV cell with clearly outlined Ag peaks. 
Amongst the organic solvents used, hexane exhibited the greatly desirable ability to cause EVA dissolution with relative ease while keeping the PV cells intact. In this sense, the silicon PV cells can effectively be reused and thereby reduce the heavy cost associated with the production of silicon PV cells. Hexane also has relatively reasonable volatility thereby allowing for easy recovery and reuse, with minimal energy demand. This could help in making the silicon recycling process cheaper and more attractive.

\section{Conclusions}

In this work, an organic treatment method was considered for the recovery of silicon PV cells from end-of-life PV modules by a process involving the dissolution of ethylene vinyl acetate (EVA). In the first part of the work, the parameters that were considered were the type of organic solvent, processing time and ultrasonication of the samples. Several organic solvents were initially considered before narrowing down to hexane and toluene which showed the most promising results. With previous work being carried out on the investigation of toluene as a suitable solvent for the dissolution of EVA and the recovery of PV cells, hexane became the primary solvent of investigation. In the second part of the work, a series of tests were designed to establish the performance of hexane as a solvent in the recovery of silicon PV cells. Optimization was performed in a bid to effect dissolution of the EVA with minimal to no damage to the silicon PV cells. Exposing the PV sheet section to hexane and ultrasonication for 15 minutes followed by heating to a temperature of $70{ }^{\circ} \mathrm{C}$ resulted in relatively more intact silicon PV cells. Hexane produced a percentage detachment of $86.8 \%$. Physical characterization of the obtained silicon PV cells by means of XRD revealed that the PV cell front surface morphology was intact, and that hexane had no negative effects. Considering aspects of environmental impact and PV cell defect creation, the method involving the use of hexane as a solvent can be viewed as superior to the current accepted processes of pyrolysis and combined milling and leaching operations. This shows a possibility of investigating the application of hexane as a solvent in the extraction of undamaged PV cells especially when the quality of the silicon can be maintained as solar grade.

\section{Acknowledgements}

I would like to acknowledge the support of the Fulbright Foreign Student Program for their aid in making this study possible. The support of the National Science Foundation (CHE1429768) for the purchase of the powder X-ray diffractometer is gratefully acknowledged. Notable contribution by Nikhil Dhabarde is acknowledged.

\section{References}

1. N. Eshraghi, L. Berardo, A. Schrijnemakers, V. Delaval, M. Shaibani, M. Majumder, R. Cloots, B. Vertruyen, F. Boschini and A. Mahmoud, ACS Sustain. Chem. Eng., 5879, 8 (2020).

2. F. C. S. M. Padoan, P. Altimari and F. Pagnanelli, Sol Energy, 761, 177 (2019). 
3. A. Domínguez and R. Geyer, Resour Conserv Recycl, 41, 127 (2017).

4. S. Kang, S. Yoo, J. Lee, B. Boo and H. Ryu, Renew. Energ., 159, 47 (2012).

5. T. Doi, I. Tsuda, H. Unagida, A. Murata, K. Sakuta and K. Kurokawa, Sol. Energy Mater Sol. Cells, 403, 67 (2001).

6. R. Meena, S. Kumar and R. Gupta, Solar Energy, 122, 203 (2020).

7. M. F. Azeumo, C. Germana, N. M. Ippolito, M. Franco, P. Luigi and S. Settimio, Sol. Energy Mater Sol. Cells, vol. 319, 193 (2019).

8. W. H. Huang, W. J. Shin, L. Wang, W. C. Sun and M. Tao, Sol Energy, 31, 144 (2017).

9. C. S. Tao, J. Jiang and M. Tao, Sol. Energy Mater Sol. Cells, 3180, 95 (2011).

10. Y. Fu, X. Liu and Z. Yuan, J. Clean. Prod., 190, 86 (2015).

11. P. Dias, S. Javimczik, M. Benevit and H. Veit, Waste Manage., 722, 60 (2016).

12. B. Jung, J. Park, D. Seo and N. Park, ACS Sustain. Chem. Eng., 4083, 4 (2016).

13. M. Goe and G. Gaustad, Sol. Energy Mater Sol. Cells, 36, 156 (2016).

14. G. Granata, F. Pagnanelli, E. Moscardini, T. Havlik and L. Toro, Sol. Energy Mater Sol. Cells, 248, 123 (2014).

15. F. Pagnanelli, E. Moscardini, G. Granata, T. A. Atia, P. Altimari, T. Havlik and L. Toro, Waste Manage., 431, 59 (2017).

16. Y. Akimoto, A. Iizuka and E. Shibata, Miner. Eng., 9, 125 (2018).

17. S. M. Nevala, J. Hamuyuni, T. Junnila, T. Sirvio, S. Eisert, B. P. Wilson, R. SernaGuerrero and M. Lundstrom, Waste Manage., 50, 87 (2019).

18. R. Wang, E. Song, C. Zhang, X. Zhuang, E. Ma, J. Bai, W. Yuan and J. Wang, RSC $A d v ., 18123,9$ (2019).

19. M. Tammaro, J. Rimauro, V. Fiandra and A. Salluzzo, Renew. Energ., 112, 81 (2015).

20. W. Berger, F. G. Simon, K. Weimann and E. A. Alsema, Resour Conserv Recycl, 718, 54 (2010).

21. Y. Kim and J. Lee, Sol. Energy Mater and Sol. Cells, 322, 98 (2012).

22. J. Park, W. Kim, N. Cho, H. Lee and N. Park, Green Chem., 1714, 18 (2016).

23. J. K. Lee, J. S. Lee, Y. S. Ahn, G. H. Kang, H. E. Song, J. I. Lee, M. G. Kang and C. H. Cho, Sol. Energy Mater Sol. Cells, 306, 160 (2017).

24. J. Shin, J. Park and N. Park, Sol. Energy Mater Sol. Cells, 6, 162 (2017).

25. G. A. Heath, T. J. Silverman, M. Kempe, M. Deceglie, D. Ravikumar, T. Remo, H. Cui, P. Sinha, C. Libby, S. Shaw, K. Komoto, K. Wambach, E. Butler, T. Barnes and A. Wade, Nat. Energy, 510, 5 (2020).

26. E. R. Sadiku, A. Babul Reddy, D. Gnanasekarana, B. Oboirien, B. A. Aderibigbe, K. Varaprasad and S. M. R. Goddeti, in Design and Applications of Nanostructured Polymer Blends and Nanocomposite Systems, p. 259, Elsevier, Oxford, (2016).

27. B. A. Miller-Chou and J. L. Koenig, Prog. Polym. Sci., 1270, 28 (2003).

28. B. Narasimhan and N. A. Peppas, Macromolecules, 3291, 29 (1996).

29. K. Ueberreiter, in Diffusion in polymers, p. 257, Academic Press, New York (1968).

30. R. D. Arjanggi and J. Kansedo, J. Energy Inst., 952, 93 (2020).

31. A. C. Ouano and J. A. Carothers, Polym. Eng. Sci., 166, 20 (1980).

32. J. D. Robert and M. C. Caserio, in Basic Principles of Organic Chemistry, Menlo Park: W. A. Benjamin, Inc., California (1977). 